\title{
Family network of children with special health needs: implications for Nursing
}

\author{
Eliane Tatsch Neves ${ }^{1}$ \\ Ivone Evangelista Cabral² \\ Andressa da Silveira ${ }^{3}$
}

\begin{abstract}
Objective: to describe appropriate sources and resources for caregivers of children with special health needs in the community. Method: A qualitative study that used the creativity and sensitivity dynamics speaking map, part of the sensitive creative method, involving 11 caregivers of children with special health needs who are assisted in a university hospital located in the South of Brazil. Results: the maps graphically represented through the genogram and ecomap showed that the caregiving women consistently and regularly use the resources of the internal and external family network; they eventually and irregularly access the community social network for physical and psychological support. Conclusion: the reclusive nature of care for these children inside the family circle contributes to their social invisibility. Based on this new information, it is recommended that Nursing participate in the care that is focused on these children's families, with particular attention to their socio-cultural conditions.
\end{abstract}

Descriptors: Child Health; Pediatric Nursing; Caregivers; Social Support.

\footnotetext{
${ }^{1}$ PhD, Adjunct Professor, Centro de Ciências da Saúde, Universidade Federal de Santa Maria, Santa Maria, RS, Brazil.

2 PhD, Associate Professor, Escola de Enfermagem Anna Nery, Universidade Federal do Rio de Janeiro, Rio de Janeiro, RJ, Brazil.

${ }^{3}$ MSc, Assistant Professor, Universidade Federal do Pampa, Bagé, RS, Brazil.
} 


\section{Introduction}

The denomination children with special health care needs (CSHCN) includes those who have limiting or disabling motor, functional, behavioral, emotional and/or developmental conditions; those with chronic disorders; and even those with a higher risk of having them. These are children who present a continuous demand for care on a temporary or permanent basis, and depend on a large number of special healthcare and social services, beyond what is required for children in general(1-4). It relates to an emerging children's group from those places in the world that increased children's access to social and health technologies and improved their living conditions. In the United States, for example, it is estimated that there are between $15 \%$ and $18 \%$ of $\mathrm{CSHCN}^{(5-6)}$.

In Brazil, however, these children are kept in the invisibility of statistics dealing with children's morbidity and mortality. There are records of their existence in some places, like in the city of Rio de Janeiro, located in the state of Rio de Janeiro, and in the city of Santa Maria, located in the state of Rio Grande do Sul.

In Rio de Janeiro, between 1997 and 2001, the CSHCN represented $74.2 \%$ of patients in neonatal intensive care and $6.3 \%$ of patients in pediatric intensive care ${ }^{(7)}$. In the city of Santa Maria (Rio Grande do Sul), they constituted $58.5 \%$ of the children receiving outpatient care at a teaching hospital(7) in 2005.

In both studies, mothers have been identified as the primary caregivers for the children, followed by other women in the family. In the city of Santa Maria, particularly, mothers were the primary caregivers in $92 \%$ of the cases; in their absence, other women who were part of the blood or affective family took the role of secondary caregivers (grandmothers, aunts and godmothers $)^{(7)}$. These data pointed to the fact that care for the CSHCN is provided by the family and centered in the women.

These women face various complex and intense care demands that require constant risk supervision. Much of the care involves nursing procedures, which families have to incorporate into their daily care routine, beyond that required for children in general. For example, bathing a child with tracheostomy entails the risk of drowning; feeding a child through enteral tube causes the risk of bronchial aspiration; administering anticonvulsant medication carries a potential risk of under or overdose due to the constant change of children's weight. Even when moving a child in a wheelchair, there is the need for the family caregivers to overcome the challenges of accessibility and mobility. In this sense, nursing knowledge and practices need to be included in the family care network, since the care skills that family caregivers have as a result of their experience in taking care of children as part of the family routine are insufficient to provide the complex care required at home and in the community.

In addition to the complexity of care problem, family caregivers, mostly women, still have to deal with the intense, continuous and permanent nature of this care provided to the children, which requires exclusive dedication to meet so many demands. In the daily family routine, little is known about the family care network, the members of the family who are part of this network, their organizational structure and what resources they have to provide this care.

Furthermore, mediating the necessary knowledge for the development of care to the CSHCN is also a challenge for nursing professionals, as they are faced with patients who have to be readmitted to hospital more often than others(7), but who remain invisible in the Brazilian public health policies.

Based on this, before the nursing team can negotiate for the knowledge and practices related to nursing procedures to be incorporated into these children's care at home, they need to know the family resources and organizational structure. The multiplicity and complexity of care demands require a heavy load and intense dedication to the children, particularly from the women in the family. It is necessary to recognize that the combination of these aspects can affect the quality of life of these children, and create a cruel environment of guilt of the women, who in this context are as much a victim as the children.

Therefore, this study was focused on family articulation in care to the children, with the purpose of describing the appropriate sources and resources for caregivers of children with special health care needs in the community.

The family organizational structure and the resources adopted by the family to articulate the family network can be graphically represented through a 
genogram and an ecomap. These are instruments used in the Calgary Model of Family Assessment and Intervention to permit the visualization of the internal and external family structure when providing care to other family members ${ }^{(8)}$. In order to discuss the articulation of the family in providing care to the CSHCN out of the hospital environment, the empowerment framework was used under the critical-liberating perspective.

\section{Method}

This is a qualitative and participatory research with a critical humanistic approach, based on the Creative Sensitive Method (CSM) of data collection(9). The Dynamics of Creativity and Sensitivity (DCS) Speaking Map was developed with the participation of 11 female caregivers of CSHCN living in the rural and city areas of a state located in the South of Brazil. The research scenario was a pediatric unit of a large university hospital, which is a reference for the Unified Health System (SUS).

Through the DCS Speaking Map, the relationships of female caregivers of $\mathrm{CSHCN}$ with their families and with the community environment were investigated. The leading question (LQ) for the debate - "Taking your home as a starting point, please draw a map identifying the places where you take your son/daughter and who are the people assisting you to take care of them?" encouraged the group of women to develop an artistic production. On the map, the caregivers recorded the places in the community where they took the CSHCN, and the people who assisted them with providing this care. In presenting what was produced, they explained about the places and people in the family network, promoted a group discussion and generated the research material, which was subject to analysis.

In the preliminary reading of the primary sources (artistic production and product of the group discussion), the set of statements showed that the events relating to the care the women provided to the CSHCN were full of emotional and experiential content, which led to the option to use French discourse analysis (DA). For DA, the notion of subject and the conditions of speech production are essential for discourse analysis. In turn, the language used by the subjects to mean what they say and what they do not say is not clear. People's discourse consists of and are not crossed by meanings ${ }^{(10)}$. In order to understand what people say, it is necessary to analyze how stated data are produced, under what conditions they were produced and what meaning effects can be learnt from them.

The first stage of the analytical process consisted in assigning linguistic materiality to the subjects' discourse so that, during the reading, readers can transport themselves to the moment of the statement and understand the conditions of their production. Some orthographic resources were used to materialize the object of discussion, which were $-/$ : short reflective pause; //: long reflective pause; ...: incomplete thought; ///: very long reflective pause; \#: interruption of a person's discourse etc.

In the second stage of the analysis, the object of speech is shown after successive readings and rereadings of the research material. At this stage, the language resources used by the subjects to give a meaning to what they said are identified. In the view of the discourse analyst, these are analytical tools in the field of DA - the metaphor, the interdiscourse, the paraphrase and polysemy processes ${ }^{(10)}$ - essential to reveal the meaning effects of what was said and not said by these study participants.

The study received approval from the Research Ethics Committee of the institution under registration number 093/2004 and all participants signed the Informed Consent Form, after receiving clarifications about the purpose of the study and agreeing to voluntarily participate in the research. In order to ensure the anonymity of the women who participated in this study, they were given fictitious names.

\section{Results}

In presenting the artistic production, caregivers explained what they drew on the map:

Here is my house. My mother's and my sister-in-law's house, who live in the same block as me. Here is the physiotherapy clinic where I take " $V$ " (2 years, 4 months) everyday... and here is the APAE, where, after leaving the physiotherapy, she goes to do speech therapy exercises. On Tuesdays, she also has early stimulation classes. And here... where I take her on Saturdays, here at the University, it is the water aerobics. Here is the church, where I take her. (Rose) 


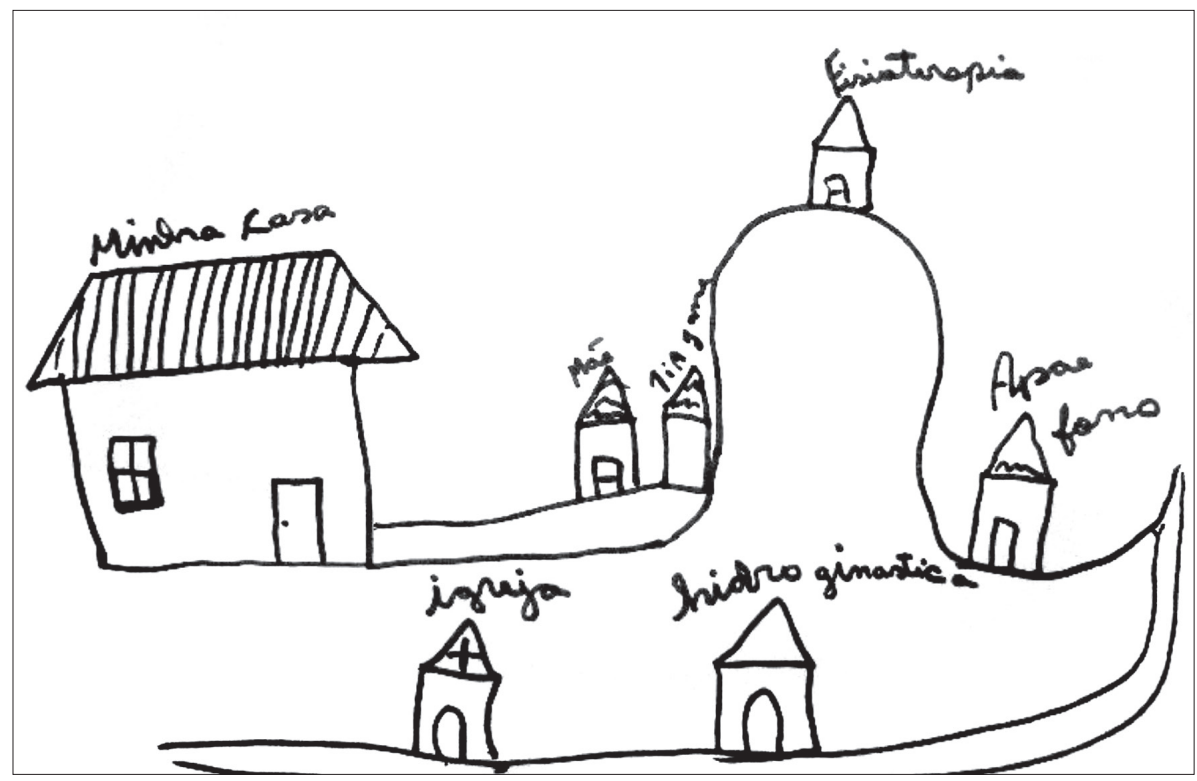

(My house - Mother - Aunt Jane - Physiotherapy- APAE speech therapy - Water aerobics - Church)

Figure 1 - Rose's artistic production (My house - Mother - Aunt Jane - PhysiotherapyAPAE speech therapy - Water aerobics - Church)

The mother is the primary caregiver of a child with special health care needs, aged 2 years and four months, who depends on various social and health services to perform physiotherapy, speech therapy, early stimulation, and water aerobics, besides followup outpatient care consultations at a teaching hospital. The child has a limiting and organic dysfunctional motor condition from birth.

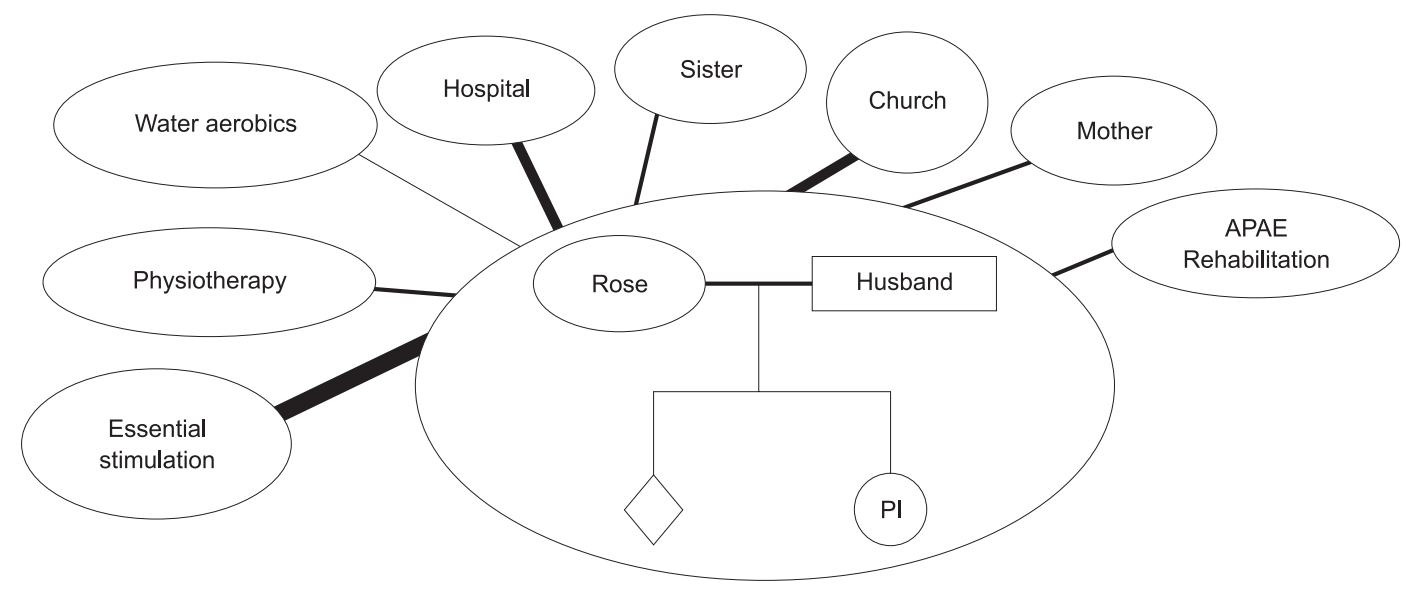

\begin{tabular}{c|c|c|c|c|c}
\hline \multicolumn{6}{c}{ Genogram and Ecomap's reading caption } \\
\hline $\begin{array}{c}\text { Strong } \\
\text { connections }\end{array}$ & $\begin{array}{c}\text { Moderate } \\
\text { connections }\end{array}$ & $\begin{array}{c}\text { Superficial } \\
\text { connections }\end{array}$ & Female & \\
\hline $\begin{array}{c}\text { Very superficial } \\
\text { connections }\end{array}$ & - & Male & & & \\
\hline $\begin{array}{c}\text { Undefined } \\
\text { gender }\end{array}$ & $-\begin{array}{c}\text { Index } \\
\text { person }-\mathrm{CSHCN}\end{array}$ & $\mathrm{Pl}$ & & \\
\hline
\end{tabular}

Figure 2 - Rose's Genogram and Ecomap

In transferring the information from the artistic production (AP) into the genogram and ecomap (Figure 2 ), it could be noted that Rose is one of the caregivers who have a wide social network, has strong connections with her mother and sister who are part of the family network, and with the physiotherapy network. This network is, 
however, scattered due to the geographical distance from her home to the several healthcare units, and sometimes she needs to travel to another city and go to different places for each type of service required for the child.

The schedule of weekly appointments with professionals of various specialties, located in different units, shows how intensive her dedication is and the exclusivity that the child imposes on her life.

In addition to the challenge posed by the complexity of the care provided to the $\mathrm{CSHCN}$ at home, these caregivers need to manage a complex and spread schedule of appointments, including several institutions and locations.

During the dialogue, the researcher asks Rose why she drew the physiotherapy unit on top of a hill, to which Rose replied that it was not a hill nor a steep street, but: - I don't know, (laughs) it is the highway () It is of a hill (based on the way she thought) but it is not (Rose). Rose does not know why she drew the physiotherapy unit on top of a hill, as the drawing shows a geographically defined hill. In her view, the hill is not a "hill", but a highway, stressed by her statement and by the association with a hill, making her state what "it is" and what "it is not".

Based on this, the belief in the cure that these caregivers have in the physiotherapy is consolidated, considering that it is the physiotherapy that enables them to see advances in their children's movements. Physiotherapy acts on the functional recovery of the children and caregivers believe and hope that the children are able to walk. Physiotherapy has a polysemic effect on the lives of these caregivers, as it produces a new meaning for their lives. The hope that the children could have some autonomy is strengthened with physiotherapy intervention. Therefore, caregivers seek health recovery more focused on functional recovery.
Back to the dialogue with Rose, she reiterates when asked about the places where she feels stronger: It is in the physiotherapy unit. (...) I don't know!! Yes, I // have hope that she is going to walk. Still have faith // And I like to take her to the other places too // But I like more to take her to the physiotherapy and / try. (Rose)

Mediated by metaphorical and polysemic processes, Rose based the meaning of what she had stated on the empowerment of attempting to take care of her daughter, having as the central point of support the physiotherapy, and other places as secondary support. She had the "hope" that her daughter could one day walk centered in the physiotherapy. Much more than hope, this is a belief. In general, this view of the physiotherapy is noted in the statements of all caregivers who participated in this study.

Raquel, another caregiver, also mentions the close family and spirituality as community resources from which she receives support to take care of her two CSHCN children. Raquel described her AP in her statement, as follows: (...) Here is the // the ... the church where we also take them every Saturday. Here is the grandmother's house, where we often go. The godmothers' house... where we also go very often. There is a lot of support. Here too //it is ... the godmother's. It is his other godmother, who is from here. We come here often. And here it is in the physiotherapy unit, where we also come. (...). (Raquel)

Raquel gave a polysemic meaning when referring to the godmothers' and grandmother's house, repeating the work "often" (intensifying adverb) to indicate the support received in these places. On the travel undertaken by Raquel to the several institutions, she includes her children in the social life of the family and indicates that she takes them to birthday parties and other parties, which means that where they go, they take them.

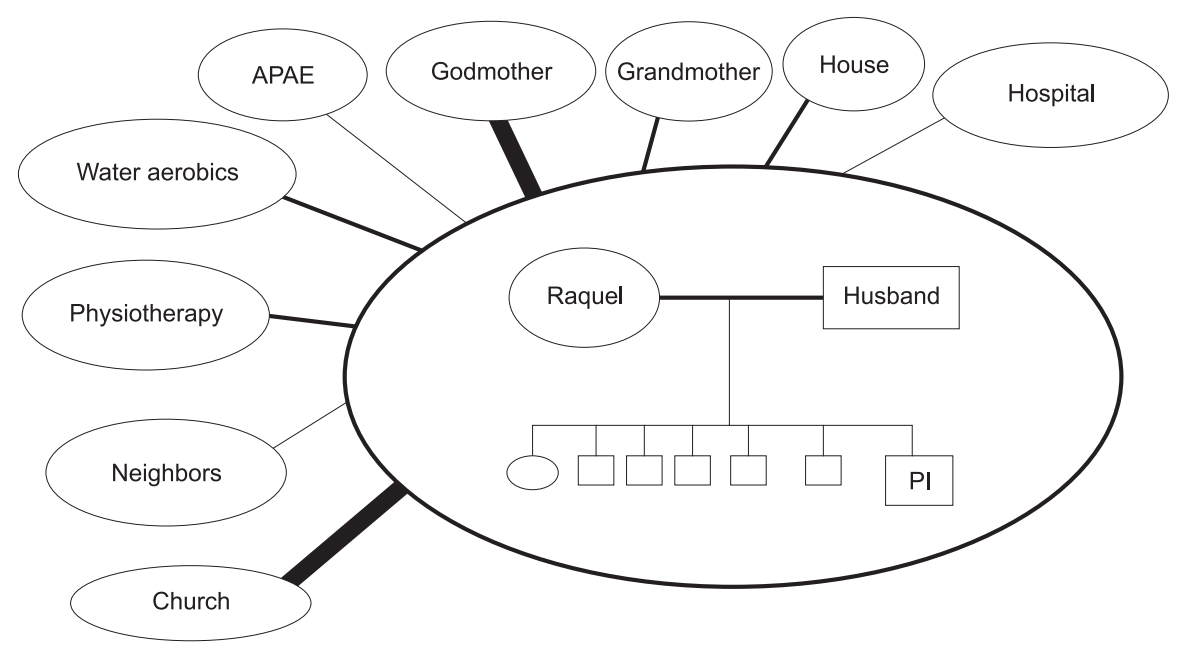

Figure 3 - Raquel's genogram and ecomap 
It can be noted in Figure 3 that, although Raquel has a wide network, she feels really supported by the family network (godmothers' and grandmother's house). Her justification for this is that, at these places, she receives support and there is dialogue. The church is where she feels strong, as it is there that she seeks divine cure through faith and looks to God for strength to take care of her two children with health special needs.

The lack of information about the services offered, such as the water aerobics offered to these children by the institution, was noted during data collection. Some caregivers heard about these services during the DCS.
This fact is partly due to the lack of family groups or support groups to these patients in the institution and in the region, which leads the caregivers to distance themselves from the social support network and to a solitary care, thus developing individual empowerment.

On that note, Maria's case is presented, which is the life of a caregiver who develops solitary care, looking to God for strength and to the healthcare team of the study institution. Maria's speaking map, represented below by the genogram and ecomap (Figure 4), shows her limited social network and her solitary care.

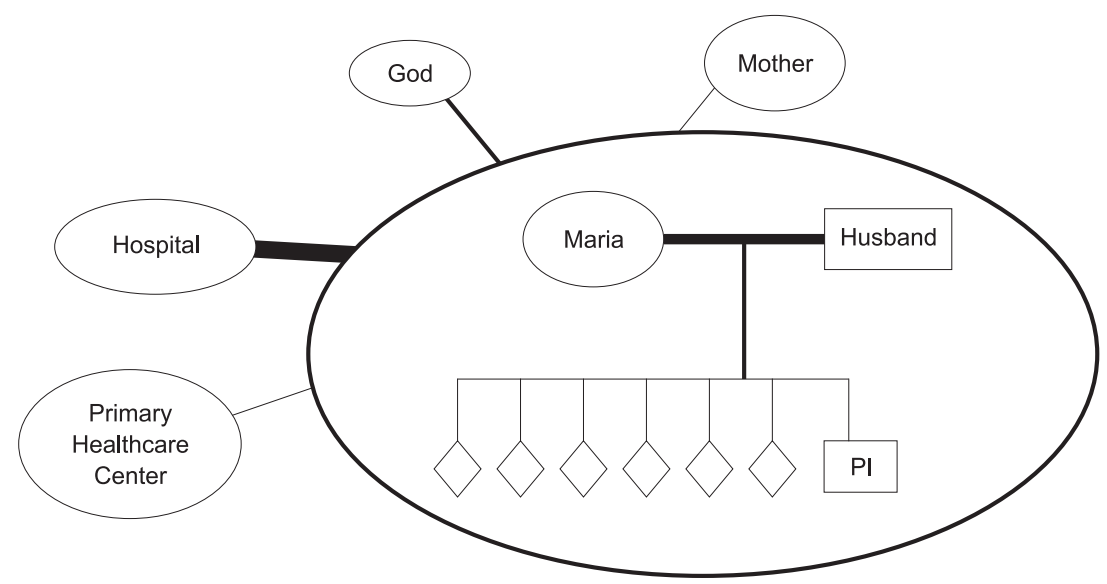

Figure 4 - Maria's genogram and ecomap

Maria based her meaning on her discourse by saying: It is because I live right on the outskirts (rural region), and I am not close friends with the neighbors. I am loooonely at home. / I don't go out often. My mother lives relatively close to me ... but she has her own things to do ... and she works!! (emphasizing the justification that her mother cannot help her much) and I don't go out of the house often ... So, my support is right here (referring to the study institution)!!! (Maria)

Maria emphasizes her loneliness, saying the word lonely with intense intonation. She finally summarizes the sources of support in her close family network, mentioning her other six children and husband. She refers to God as spiritual support and to the hospital as institutional network.

Therefore, the participants of the social network the caregivers reported as support for empowerment in the care process were the close family network, which includes the children's grandparents, aunts and godmothers, while the sources and resources included the physiotherapy unit and the church/God. In this sense, the caregivers' discourse showed the physiotherapy unit, the church, the grandmother's house and the godmothers' house as community resources they find support in to take care of their children and constitute their social support.

\section{Discussion}

Individual empowerment is triggered by an emotional response after exposure to some stressful factor $^{(11-12)}$. In turn, collective empowerment occurs when this individual joins the collective, permitting collective awareness of the need to fight for their rights and duties, seeking social transformation associated with information sharing and involving political actions in the community, associations, institutions and the government ${ }^{(13)}$.

Therefore, collective empowerment was shown in the caregivers' lives, since they share the responsibility of taking care/assisting the CSHCN with the community, establishing community care that involves other members of the family and the society through institutions and the government. Taking care of themselves and others is not an easy task and it requires articulation between people and places that are part of a social network. Especially when the other person is a CSHCN, who solely and 
exclusively depends on another person to survive and have a voice in the world(14).

The families of CSHCN had a wide social support network, but with decentralized resources. The social support can be seen as an interaction among people or groups of people, who establish connections and receive material, emotional and affective support, and build positive factors in the prevention/maintenance of health(15).

With this in mind, the caregivers who try to solve and attend to the demands to assist the CSHCN by themselves develop a sense of individual empowerment, based on spirituality and connection with some of the members of the close family circle. Considering the women's dedication to the role of primary caregiver, they are in charge of meeting the physical care needs of the children, thus limiting their relationship network with the community.

In this way, mothers give up other activities and roles, they are concerned and in charge of taking care of their sick children, and this causes certain difficulties in relation to their inner family and social relationships(16). Even those who show some sense of collective empowerment follow the socio-cultural matrix of family care centered in the mother figure and, particularly, in the women's figure (aunts, grandmothers, godmothers) and this represents not only an attempt to socialize care, but also practices passed from generation to generation.

Therefore, the close family network is the primary resource for solving issues relating to the children(2). The fact that mothers are the primary caregivers leads them to resort to family support, seeking direction and support for conducting the care process of the CSHCN.

Families of children with chronic health conditions view religion and spirituality as sources of comfort and hope, which help to better accept the children or

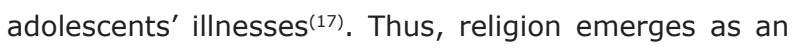
element affecting the illness experience and becomes an important coping resource. It becomes a socio-cultural system that provides emotional support, often required by the family caregiver(18).

In turn, the professional system represents the possibility of cure and children's rehabilitation and is based on an explanatory model that is far from the social and cultural scenario and language. The caregivers see the medical assistance model, focused on medical care to chronic illnesses and functional recovery of movements, as the possibility of cure, as represented by the strong relation with physiotherapy.

The caregivers' interdiscourse is marked by the history of their routine and the contact with healthcare institutions. It is noted that caregivers who do not have any knowledge have always existed and that care practice has traditionally begun in home environments. The family caregivers are recognized as sources for promoting care and develop care strategies in the community context, based on their previous experiences ${ }^{(19)}$. Therefore, the search for a normal life for children with the chronic illnesses is not part of their polysemic discourse.

Within this professional care network, the physiotherapist stands out for providing visible results, which have a polysemic meaning for caregivers. This contrasts with the findings in international literature, which point out the need for nurses to act as a link between the family caregivers of the CSHCN and the rest of the healthcare team, the latter of whom listen to the mothers ${ }^{(20)}$. These mothers have great trust in the healthcare professionals and seek to carefully listen to the information they provide about the health conditions of the children. However, national studies indicate a distance between the healthcare professional and their patients(21-23).

Therefore, chronic illnesses require changes in the life of the children/adolescents who have their daily lives changed from the time of diagnosis and in the life of their families, requiring readjustments on the face of the new situation, besides the strategies used to cope with the illness. This process depends on the complexity and severity of the illness, the stage it is at, and the services available to satisfy their needs and regain balance. This situation requires that all healthcare professionals, as well as the family member responsible for the care of the CSHCN, are more sensitive and open to create connections and accountabilities, in order to establish partnerships and access possible social support networks ${ }^{(24)}$.

\section{Conclusion}

The socio-cultural matrices that support the dedication of women to the role of primary caregivers of children are socialization, gender and family. With this dedication, they are in charge of meeting the physical care needs of the children, limiting their community relationship network. In general, this is reduced to close family members and spirituality, which results in a fragile and limited social support network.

The findings of this research converged on the need to expand the types of social support provided to caregivers through integration (support groups) and sharing of information pertaining to the existing services and institutions. 
The current health practice has been of an alienating and oppressive standard, which affects child care services, overloading women through a convincing exercise that they are the primary family caregiver and, therefore, the primary caregiver of the CSHCN. Given that empowerment is a construction that goes from the individual to the social and is mediated by collectivity, the influence of a socio-cultural dimension in this process cannot be ignored.

It is, therefore, concluded that, despite the community resources that the caregivers of the CSHCN report to be different depending on the context of life of each, they are focused on a curative principle, aimed at the recovery of the children's health. Based on this, the caregivers' relationship with the community is very far from a fight for social and political visibility and social inclusion of the CSHCN.

It is recommended that healthcare teams, in particular Nursing, be present to show the way of providing care to the $\mathrm{CSHCN}^{\prime}$ families, giving attention to their socio-cultural conditions in the search for care focused on the family and aimed at promoting these children's health.

\section{References}

1. McPherson MG, Arango P, Fox H, Lauver C, Mc-Manus $M$, Newachek PW, et al. A new definition of children with special health care needs. Pediatrics. 1998;102(1):13741. Inglês.

2. Zamberlan KC, Neves ET, Silveira A. Rede institucional de cuidados à criança com necessidades especiais de saúde. J Nurs UFPE on line [periódico na Internet]. 2012. [acesso 25 julho 2012];6(5):1015-23. Disponível em: http://www.ufpe.br/revistaenfermagem/index. php/revista/article/view/2395/pdf_1268.

3. O $\square$ Brien ME. Living in a house of cards: family experiences with long-term childhood technology dependence. J Pediatr Nurs. 2001;16(1):13-22. Inglês. 4. Perrin JM, Romm D, Bloom SR, Homer CJ, Kuhlthau KA, Cooley C, et al. A Family-Centered, CommunityBased System of Services for Children and Youth With Special Health Care Needs. Arch Pediatr Adolesc Med. 2007;161(1):933-6.

5. Cabral IE, Silva JJ, Zillmann DO, Moraes JR, Rodrigues EC. A criança egressa da terapia intensiva na luta pela sobrevida. Rev Bras Enferm. 2004;57(1):35-9.

6. Hockenberry MJ, Wilson $\mathrm{D}$, Winkelstein ML. Wong Fundamentos da enfermagem pediátrica. 7th ed. Rio de Janeiro: Elsevier; 2006. 1344 p.
7. Vernier ETN, Cabral IE. Caracterização de crianças com necessidades especiais de saúde e seus familiares cuidadores. Santa Maria (RS). 2004-2005: subsídios para intervenções de enfermagem. Rev Soc Bras Enferm Pediatr. 2006;6(1):37-45.

8. Silva L, Bousso RS, Galera SAF. Aplicação do Modelo Calgary para avaliação de famílias de isodos na prática clínica. Rev Bras Enferm. 2009;62(4):530-4.

9. Cabral IE. O método criativo e sensível: alternativa de pesquisa na enfermagem. In: Gauthier JHM, Cabral IE, Santos I, Tavares CMM. Pesquisa em enfermagem: novas metodologias aplicadas. Rio de Janeiro: Guanabara Koogan; 1998. p. 177-203.

10. Orlandi EP. Análise de Discurso: princípios e procedimentos. 8a ed. Campinas (SP): Pontes, 2009. $100 \mathrm{p}$.

11. Rappaport J. Studies in empowerment: introduction to the issue. Prevention in Human Services.1984;3(2/3):1-7. Inglês.

12. Kleba ME, Wendausen A. Empoderamento: processo de fortalecimento dos sujeitos nos espaços de participação social e democratização política. Saúde e Sociedade [periódico na Internet]. 2009. [acesso 28 out 2012]; 18(4):733-43. Disponível em: http://www. scielo.br/pdf/sausoc/v18n4/16.pdf.

13. Martins PC, Cotta RMM, Batista RS, Mendes FF, Franceschinni SCC, Priore SE, Dias G. Democracia e empoderamento no contexto da promoção da saúde: possibilidades e desafios apresentados ao Programa de Saúde da Família. Physis Revista de Saúde Coletiva [periódico na Internet]. 2009. [acesso 28 out 2012]; 19(3):679-94. Disponível em: http://www.scielo.br/ pdf/physis/v19n3/a07v19n3.pdf.

14. Moraes JRMM, Cabral IE. The social network of children with special healthcare needs in the (in) visibility of nursing care. Rev. Latino-Am. Enfermagem. 2012;20(2):282-8. Inglês.

15. Pedro ICS, Rocha SMM, Nascimento LC. Social support and social network in family nursing: reviewing concepts. Rev. Latino-Am. Enfermagem. 2008;16(2):324-7. Inglês.

16. Quirino DD, Collet N. Cancer among infants: adjustments in family life. Texto Contexto Enferm. [periódico na Internet]. 2012. [acesso 28 out 2012] 21(2):295-303. Disponível em: http://www.scielo.br/ pdf/tce/v21n2/en_a06v21n2.pdf. Inglês.

17. Nascimento LC, Oliveira FCS, Moreno MF, Silva FM. Cuidado espiritual: componente essencial da prática da enfermeira pediátrica na oncologia. Acta Paul Enferm. $2010 ; 23(3): 437-40$. 
18. Pizzignacco TP, Mello DF, Lima RG. The experience of disease in cystic fibrosis: the paths to comprehensive care. Rev Esc Enferm USP. [periódico na Internet]. 2011. [acesso 28 out 2012]; 45(3):636-42. Disponível em: http://www.scielo.br/pdf/reeusp/v45n3/en_v45n3a13. pdf. Inglês.

19. Souza LM, Wegner W, Gorini MIPC. Health education: a strategy of care for the lay caregiver. Rev. Latino-Am. Enfermagem. [periódico na Internet]. 2007. [acesso 28 out 2012]; 15(2): 337-43. Disponível em: http://www. scielo.br/pdf/rlae/v15n2/v15n2a22.pdf. Inglês.

20. Gibson $\mathrm{CH}$. The process of empowerment in mothers of chronically ill children. J Adv Nurs. 1995;21:1201-10. Inglês.

21. Neves ET, Cabral IE. Empoderamento da mulher cuidadora de crianças com necessidades especiais de saúde. Texto Contexto Enferm. 2008;17(3):552-60.

22. Neves ET, Cabral IE. A fragilidade clínica e a vulnerabilidade social das crianças com necessidades especiais de saúde. Rev Gaúcha Enferm. 2008;29(2):18290.

23. Silveira A, Neves ET. Crianças com necessidades especiais de saúde: tendências das pesquisas em enfermagem. Rev Enferm UFSM. 2011;1(2):254-60.

24. Silva MAS, Collet N, Silva KL, Moura FM. Cotidiano da família no enfrentamento da condição crônica na infância. Acta Paul Enferm. 2010;23(3):359-65. 